\title{
A BASELINE QUANTIFICATION OF AGRICULTURAL WATER USE EFFICIENCY OVER INDIAN REGION USING GEO-LEO SATELLITES
}

\author{
Indrani Choudhury ${ }^{1,2}$, B.K. Bhattacharya ${ }^{1}$, R. Eswar ${ }^{3}$ and M.Sekhar ${ }^{3}$ \\ ${ }^{1}$ Space Applications Centre, ISRO, Ahmedabad (indrani@sac.isro.gov.in; bkbhattacharya@sac.isro.gov.in) \\ ${ }^{2}$ Department of Science and Technology, New Delhi (icaug4@yahoo.com) \\ ${ }^{3}$ Department of Civil Engineering, Indian Institute of Science, Bangalore (eswar1204@gmail.com; sekhar.muddu@gmail.com)
}

Commission III, WG III/10

KEY WORDS: Agriculture, Consumptive water use, remote sensing, food security

\begin{abstract}
:
The agricultural water use efficiency (AWUE) over India was evaluated during 2009-2014 through three steps e.g. productivity mapping using MODIS GPP; consumptive water use (CWU) mapping in terms of evapotranspiration (ET) partioned into green $\left(\mathrm{CWU}_{\mathrm{g}}\right.$; ET streaming from rainfall) and blue $\left(\mathrm{CWU}_{\mathrm{b}}\right.$; ET streaming from irrigation) water; AWUE mapping i.e. the ratio of the seasonal sum of GPP and CWU in terms of green $\left(\mathrm{AWUF}_{\mathrm{g}}\right)$ and blue $\left(\mathrm{AWUF}_{\mathrm{b}}\right)$ water. The CWU was estimated from seasonal sum of crop ET $\left(\mathrm{ET}_{\mathrm{c}}\right) . \mathrm{ET}_{\mathrm{c}}$ was obtained from composite crop co-efficient from INSAT and corresponding reference ET $\left(\mathrm{ET}_{0}\right)$, where daily $\mathrm{ET}_{0}$ was estimated using daily solar insolation (Kalpana-1VHRR) and metrological data from Weather Research and Forecasting (WRF) variables through data fusion in FAO-56 framework. Monthly effective rainfall (ER) was estimated from daily NOAA CPC rainfall data using USDA SCS method. Actual ET $\left(\mathrm{ET}_{\mathrm{a}}\right)$ was estimated using single-source surface energy balance framework with thermal observations from MODIS and MERRA reanalysis data. The $\mathrm{CWU}_{\mathrm{g}}$ at seasonal scale was determined using ER, $\mathrm{ET}_{\mathrm{a}}$ and $\mathrm{CWU}$, whereas $\mathrm{CWU}_{\mathrm{b}}$ was estimated as the difference between $\mathrm{ET}_{\mathrm{a}}$ and $\mathrm{CWU}_{\mathrm{g}}$ followed by estimation of $\mathrm{AWUE}_{\mathrm{g}}$ and AWUE $E_{b}$. The average $A W U E_{g}$ and $A_{W W E}$ during kharif and rabi seasons were found to be $1.13 \mathrm{kgCm}^{-3}$ and $1.25 \mathrm{kgCm}^{-3}$ respectively with highest share goes to Indo-gangetic plains due to high crop intensification. The arid and semiarid tract showed low AWUE. The baseline assessment of satellite based AWUE at country scale providesa scope for better management of agricultural water with respect to food security.
\end{abstract}

\section{INTRODUCTION}

Agriculture is the largest user of water and the most sensitive industry because climate change impact influences on rainfall pattern and drought (Yooet al. 2015). The crop productivity and phenology are influenced due to the increase in temperature and high $\mathrm{CO}_{2}$ concentration (Sim et al. 2010) and consequently affects the water resources and crop productivity. So it is important to consider the two components at the same time. Therefore, there is a need to measure the water use efficiency in agricultural sector in conjunction with productivity and water consumed that estimates agricultural (crop) productivity per unit of consumptive water use (CWU), an indicator to analyse the inter-relationship between water use and crop yield. The possible biggest saving in water is likely to come from growing more food with less water i.e. increasing water productivity (WP) of crop or "more crop per drop" philosophy (Khan et al. 2006). There are many studies concerning the increasing threat of water scarcity and vulnerability of water resources at regional and global scales concerning the impact on food security (Vorosmartyet al. 2000; Oki and Kanae, 2006). Measures have been sought to produce more food with less water by increasing crop water productivity (Kijneet al. 2003; Bouman, 2007; Choudhury and Bhattacharya, 2018).Given the close relationship between water and food, a systematic assessment of CWU'sand its efficiency in agriculture at regional scale is essential for strategic decision-making on food security. For crop production, CWU refers to the total evaporative use of a crop during the crop growth period, often termed "evapotranspiration (ET)". The CWU in agriculture generally breaks down into three components: the blue, green and grey water (Chapagain and Hoekstra, 2011). The present study is focusing on green and blue water uses where green water is the volume of water evaporates from green water resources (i.e.ET streaming from rainfall) and blue water is the volume of water evaporates from blue water resources (i.e. ET streaming from irrigation water e.g. surface and ground water, etc.) (Lee, 2013). The concepts of blue and green water were proposed firstly by Falkenmark (1995) at the conference held by the Food and Agriculture Organization of the United Nations (FAO).Both $\mathrm{CWU}_{\mathrm{g}}$ and $\mathrm{CWU}_{\mathrm{b}}$ resources are important for food production and without segregating the two types, the water use assessments remain incomplete. Understanding the geographic distribution of CWU's and agriculture water requirements allows the prediction of future trends in agricultural production and trade. Despite the progress made in these water use assessments, studies either lack spatial details or are limited to blue water uses at global scale or focus on water withdrawal while ignoring consumptive water uses (Seckler et al. 1998; Shiklomanov and Rodda, 2003). Hoekstra and Hung (2002) were the first to make a global estimate of the consumptive water use for a number of crops per country, but they did not explicitly distinguish consumptive water use into a green and blue component. Rockstrom and Gordon (2001) made first global estimates of green water consumption. Chapagain and Hoekstra (2004) improved this study in a number of respects, but still did not explicitly distinguish between green and blue water consumption.Global estimate of agricultural green and blue water consumption were made for agricultural crops (Rost et al. 2008,Siebert and Doll, 2010; Liu et al. 2009; Liu and Yang, 2010).But the studies did not explain the scope of satellite observations for assessments of consumptive uses of green and blue water and its utilization efficiency at regional scale. Against this background, the present study was 
conceptualized to quantify the agricultural water use efficiency over diverse agro-climatic regions of India using satellite data from both geostationary and polar orbits. The objective of the study is to segregate and estimate green and blue water uses and its utilization efficiency during kharif and rabi seasons. The CWU's were quantified by considering actual water uses through actual ET, effective rainfall and agricultural water demand (AWD) by the crop production at the regional scale.

\section{STUDY AREA}

The study was carried out over Indian region $\left(65-95^{\circ}\right.$ E, $5-40^{\circ}$ $\mathrm{N})$. The study area has diverse crops and cropping pattern grown in both kharif (July-November) and rabi (November/December-April) seasons and is based on both Southwest (SW) and Northeast (NE) monsoon. The kharif crops are entirely influenced by the SW monsoon and rabi crops are dependent on both irrigation and monsoon. In northern parts of India, the kharif season is coinciding mostly with the SW monsoon. In southern and eastern parts, the NE monsoon, is of great significance to agriculture with positive impact on rice and maize productions. In kharif season, the major crop grown is rice whereas in rabi season, the major crops are rice, wheat, potato, mustard, gram and barley. In addition, different agroclimatic zones have dynamic agricultural activities representing different crop types and management practices. Figure 1 depicts the land use land cover (LULC) map of India generated from MODIS land cover along with its agro-climatic zone boundary (Zone boundaries are based on the variability of climate, soil, vegetation and physiography as defined by the Planning Commission, India, 1989 (http://agriinfo.in).

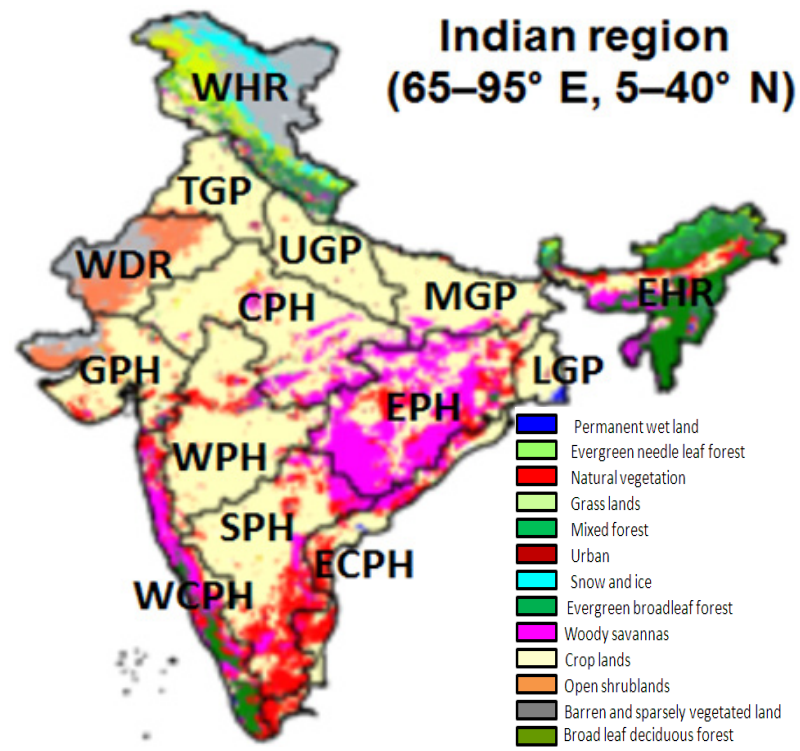

Figure 1: Study area generated from MODIS global land cover data showing different land covers with agro-climatic zone boundary (Abbreviation of the agro-climatic zones are: WHR: Western Himalayan Region; TGP: Transgangetic plains; UGP: Upper Gangetic Plains; MGP: Middle Gangetic plains; LGP: Lower Gangetic Plains; ECPH: East coast plains and Hills; WCPH: West coast plains and Hills; EPH: Eastern Plateau and Hills; CPH: Central Plateau and Hills; WPH: Western Plateau and Hills; SPH: Southern Plateau and Hills; GPH: Gujarat plains and Hills; WDR: Western Dry region).

\section{DATA AND METHODS}

\subsection{Satellite data}

3.1.1. Indian geostationary satellite data: The10-day composite INSAT 3A CCD NDVI data at $1 \mathrm{~km}$ spatial resolution during January 2010 to April 2014 were used to estimate fractional canopy cover $(f c)$.

The daily surface insolation product of Kalpana-1 VHRR (K1VHR-DAILYINS) at $8 \mathrm{~km}$ spatial resolution during 2009 to 2014 were used as one of the input in estimating reference ET $\left(\mathrm{ET}_{0}\right)$.

INSAT 3A CCD and Kalpana-1 VHRR data available in ' $h$ 5' (Hierarchal Data Format Version 5) file format were geocorrected using the associated latitude and longitude files and were projected to geographic lat/long at 0.01 and 0.08 degree respectively, with datum WGS 84 .

3.1.2 Polar orbiting satellite data: The16-day composite MODIS NDVI data at $1 \mathrm{~km}$ spatial resolution were used during July to December (2009) to estimate $f c$ due to non-availability of INSAT data during that period and were corrected with INSAT estimated $f c$.

Global data of MODIS land cover products (MCD 12Q1) at 500 m spatial resolution were used during 2009 to 2014 to generate information on different land covers and crop lands for the respective years over Indian region. The study area has 15 agroclimatic zones with varying climate, soil types, land forms etc. In the present study, the analysis was carried out for 14 agroclimatic zones due to data availability.

Both MODIS land cover and NDVI data products were available in tiles in sinusoidal projection and 12 tiles (e.g. h23V05, h24V05, h24V06, h24V07, h25V05, h25V06, h25V07, h25V08, h26V05, h26V06, h26V07, h24V08) were mosaicked together using ENVI image processing software to generate the study area and was projected to geographic lat/long at 0.01 degree with datum WGS 84.

The 8-day composites land surface temperature (LST) and the surface reflectance data at $0.05^{\circ}$ degree (Climate Modelling Grid) were used for $\mathrm{ET}_{\mathrm{a}}$ product generation along with reanalysis data.

3.1.3. High-resolution weather forecast (WRF) data: The daily three-hourly operational high-resolution $(3 \mathrm{~km})$ shortrange weather forecasts on temperature (maximum and minimum i.e. $\mathrm{T}_{\max }$ and $\mathrm{T}_{\min }$ ), relative humidity (maximum and minimum i.e. $\mathrm{RH}_{\max }$ and $\left.\mathrm{RH}_{\min }\right)$, wind speed at $10 \mathrm{~m}\left(\mathrm{u}_{10}\right)$ and atmospheric pressure $(\mathrm{P})$ from the WRF model version 3.1 were used to generate daily data of the above mentioned weather parameters. The weather parameters were obtained during kharif and rabi seasons from 2009 to 2014 and incorporated in the FAO framework along with solar insolation data to estimate daily $\mathrm{ET}_{0}$.

INSAT 3A CCD, Kalpana-1 VHRR and WRF data were acquired from Meteorological and Oceanic Satellite Data Archival Centre (MOSDAC) portal (www.mosdac.gov.in).

3.1.4. Reanalysis datasets: Modern-Era Retrospective analysis for Research and Applications (MERRA) satellite reanalysis data were obtained from the Global Modeling and Assimilation Office (GMAO). Air temperature (Ta) and incoming global solar radiation (Rsd) data were downloaded from the MERRA data portal (http://disc.sci.gsfc.nasa.gov/mdisc/) for the period 2009-2014. From the MERRA, Tavalues available for every hour in a day, the average of two values corresponding only to 5 
and 6 hours Greenwich Mean Time (10:30 and 11:30 hours Indian Standard Time, the time interval when MODIS TERRA overpass happens over India) was used in the generation of the $\mathrm{ET}_{\mathrm{a}}$ products. This was assumed to be the Taat the time of satellite overpass. In case of Rsd, the 24 hour averaged value was used. Due to the use of time composite MODIS data (LST and surface reflectance), the Taand Rsdfrom MERRA also were averaged over the corresponding days as that of MODIS LST and data. The elevation information needed for the study was obtained from the Global Multi-resolution Terrain Elevation Data (GMTED) 2010 of the United States Geological Survey (Danielson and Gesch, 2011).

\subsection{Ancillary data}

3.2.1. Statistical data: State wise commodity monitoring of Indian economy (CMIE) data of crop area statistics were collected for each state of India during the period from 2009 to 2011 for both kharif and rabi seasons (http://commodities.cmie.com) for development of $\mathrm{Kc}_{\text {comp }}$ model.

\section{3. Methods}

In order to calculate the volume of water consumed, CWU of an agricultural cluster was computed and was partitioned in to $\mathrm{CWU}_{\mathrm{g}}$ and $\mathrm{CWU}_{\mathrm{b}}$. The essential requirements are reference ET $\left(\mathrm{ET}_{0}\right)$, Agricultural water demand (AWD) i.e. the seasonal sum of crop ET $\left(\mathrm{ET}_{\mathrm{c}}\right)$, actual ET $\left(\mathrm{ET}_{\mathrm{a}}\right)$ and effective rainfall $(\mathrm{ER})$ at monthly interval. The followings are the steps:

3.3.1 Estimation of $\mathbf{E T}_{\mathbf{0}}$ at regional scale: The PenmanMonteith equation was used to generate the regional output of daily $\mathrm{ET}_{0}$ during 2009-2014, were generated through various steps as outlined by Vyas et al. (2016) using satellite based meteorological data e.g solar insolation, air temperature, relative humidity, atmospheric data and wind speed data (Allen et al. 1998) as stated below:

$$
\mathrm{ET}_{0}=\frac{0.408 \cdot \Delta \cdot(\mathrm{Rn}-\mathrm{G})+\gamma \cdot\left(\frac{900}{\mathrm{~T}+273}\right) \cdot \mathrm{u}_{2} \cdot\left(\mathrm{e}_{\mathrm{s}}-\mathrm{e}_{\mathrm{a}}\right)}{\Delta+\gamma \cdot\left(1+0.34 \cdot \mathrm{u}_{2}\right)}
$$

where $\mathrm{ET}_{0}=$ Grass reference $\mathrm{ET}\left(\mathrm{mmd}^{-1}\right)$;

$\mathrm{R}_{\mathrm{n}}=$ net radiation at the crop surface $\left(\mathrm{MJm}^{-2} \mathrm{~d}^{-1}\right)$;

$$
\mathrm{G}=\text { soil heat flux density, } \mathrm{MJm}^{-2} \mathrm{~d}^{-1} \text {; }
$$

$\mathrm{T}=$ mean daily air temperature at $2 \mathrm{~m}$ height $\left({ }^{\circ} \mathrm{C}\right)$;

$\mathrm{u}_{2}=$ wind speed at $2 \mathrm{~m}$ height $\left(\mathrm{ms}^{-1}\right)$;

$\mathrm{e}_{\mathrm{s}}=$ saturation vapour pressure $(\mathrm{kPa})$

$\mathrm{e}_{\mathrm{a}}=$ actual vapour pressure $(\mathrm{kPa})$;

$\left(\mathrm{e}_{\mathrm{s}}-\mathrm{e}_{\mathrm{a}}\right)=$ saturation vapour pressure deficit $(\mathrm{kPa})$; $\Delta=$ slope of vapour pressure curve $\left(\mathrm{kPaC}^{-1}\right)$; $\gamma=$ psychrometric constant $\left(\mathrm{kPaC}^{-1}\right)$.

At first, the 2D surface of the 24 hour averages of $T_{\max }, T_{\min }$ $\mathrm{RH}_{\max }, \mathrm{RH}_{\min }$, " $\mathrm{u}_{10}$ " and "P", from the WRF model over the Indian region were generated using the three-hourly forecasts of WRF variables at $0.03^{\circ}$ grid resolution and then resampled to $0.08^{\circ}$ grid resolution in order to make compatible with the insolation data from Kalpana-1. The daily data of solar insolation product from Kalpana-1 was projected to a geographic grid of $0.08^{\circ}$ resolution from the native Transverse Mercator (TM) projection. All these input parameters were then integrated into the FAO56 Penman-Monteith model framework to generate the daily spatial $\mathrm{ET}_{0}$ at regional scale, which were aggregated together to compute monthly accumulated $\mathrm{ET}_{0}$ over Indian agro-climatic region during 2009 to 2014.
3.3.2 Estimation of regional AWD: Composite crop coefficient $\left(\mathrm{Kc}_{\text {comp }}\right)$ model was developed using stage-specific crop-coefficient $(\mathrm{Kc})$ obtained from FAO 56 manual and weighted through crop area fraction from published statistics in a given administrative unit. The $\mathrm{Kc}_{\text {comp }}$ values for each growing stage for each administrative unit were then computed by taking the ratio of the summation of the crop area multiplied by the corresponding $\mathrm{Kc}$ value (table value from FAO56 manual) of the individual crop to the total area of all the crops grown in the particular administrative unit as stated below:

$$
\mathrm{Kc}_{\mathrm{comp}}=\frac{\sum_{i=1}^{n} a_{i \times} x_{i}}{\sum_{i=1}^{n} a_{i}}
$$

where $\mathrm{x}_{\mathrm{i}}=\mathrm{x}_{1}, \mathrm{x}_{2}, \ldots, \mathrm{x}_{\mathrm{n}}$ are the tabulated $\mathrm{Kc}$ values for individualcrop for each crop growing stage $\mathrm{a}_{\mathrm{i}}=\mathrm{a}_{1}, \mathrm{a}_{2}, \ldots \mathrm{a}_{\mathrm{n}}$ are the corresponding crop areas from CMIE data in an given administrative unit

$\mathrm{Kc}_{\text {comp }}$ values for the mid- and end-growing stages were adjusted to the local climatic conditions for kharif and rabi seasons during 2009 to 2011 by using the meteorological data i.e. wind speed $\left(\mathrm{u}_{2}\right)$ and minimum relative humidity $\left(\mathrm{RH}_{\min }\right)$ at pixel level as stated below (Allen et al. 1998):

$$
\begin{aligned}
& \mathrm{Kc}_{\text {comp mid }}=\mathrm{Kc}_{\text {comp mid(table) }}\left[0.04\left(\mathrm{u}_{2}-2\right)-0.004\left(\mathrm{RH}_{\min }-45\right)\right]\left(\frac{1}{3} \mathrm{~h}\right)^{0.3}(3) \\
& \mathrm{Kc}_{\text {comp end }}=\mathrm{kc}_{\text {comp end(table })}\left[0.04\left(\mathrm{u}_{2}-2\right)-0.004\left(\mathrm{RH}_{\min }-45\right)\right]\left(\frac{1}{3} \mathrm{~h}\right)^{0.3}
\end{aligned}
$$

Where, $\mathrm{Kc}_{\text {comp mid (table) }}=$ computed $\mathrm{Kc}_{\text {comp }}$ at mid stage $\mathrm{Kc}_{\text {comp end (table) }}=$ computed $\mathrm{Kc}_{\text {comp }}$ atend stage

$\mathrm{u}_{2}=$ mean daily wind speed at $2 \mathrm{~m}$ height over grass $\mathrm{RH}_{\min }=$ daily mean value $\mathrm{h}=$ mean plant height obtained from FAO manual.

Plant height of different crops from FAO manual were selected for a particular administrative unit corresponding to table value of $\mathrm{Kc}$ and were averaged together for the mean plant height. Daily meteorological data were obtained from the WRF forecast data.

Periods of broad crop growth stages such as early, peak vegetative and reproductive were earmarked from the temporal NDVI profile of INSAT 3A CCD 10-day (January 2010-April 2014) and MODIS 16-day (July-December 2009) composites products for both kharif and rabi seasons. The stage-specific NDVIs were converted into $f_{c}$ as stated below:

$$
f c=\left(\frac{\mathrm{NDVI}_{\mathrm{i}}-\mathrm{NDVI}_{\min }}{\mathrm{NDVI}_{\max }-\mathrm{NDVI}_{\min }}\right)^{2}
$$

where $\quad \mathrm{NDVI}_{\mathrm{i}}=\mathrm{NDVI}$ at a given pixel and at given time $\mathrm{NDVI}_{\text {max }}=$ maximum NDVI at $95 \%$ percentiles of pixels

$\mathrm{NDVI}_{\min }=$ minimum NDVI at $2 \%$ percentiles of pixels

The time series of $f \mathcal{c}$ generated during 2009 to 2011 and were fitted with pre-computed $\mathrm{Kc}_{\text {comp }}$ to develop seasonspecificKc $\mathrm{c}_{\text {comp }}$ model as stated below:

$\mathrm{Kc}_{\mathrm{comp}_{\text {kharif }}}=-15.89 * f c^{4}+6.56 * f c^{3}+5.96 * f c^{2}-1.09 * f c+0.34$ (6)
$\mathrm{Kc}_{\mathrm{comp}_{\text {rabi }}}=241.33 * f c^{4}-456.73 * f c^{3}+302.81 * f c^{2}-80.07 * f c+7.59$

where $\mathrm{Kc}_{\mathrm{comp}_{\mathrm{kharif}}}=$ kharif composite crop co-efficient $\mathrm{Kc}_{\mathrm{comp}_{\text {rabi }}}=$ rabi composite crop co-efficient 
$f c=$ fractional canopy cover

The model was used to generate distributed $\mathrm{Kc}_{\mathrm{comp}}$ at periodic interval, which were averaged together to construct monthly $\mathrm{Kc}_{\text {comp }}$ during 2009-2014 for both kharif and rabi seasons.

3.3.3 Generation of regional scale $\mathbf{E T}_{\mathbf{c}}$ : The AWD during the cropping season were estimated at regional scale using spatially distributed $\mathrm{ET}_{\mathrm{c}}$ derived at monthly interval. The spatially explicit $\mathrm{ET}_{0}$ and the corresponding $\mathrm{Kc}_{\text {comp }}$ generated at monthly scalewere used to estimate $\mathrm{ET}_{\mathrm{c}}$ (Allen et al. 1998) at monthly intervalas given below:

$$
\mathrm{ET}_{\mathrm{c}}=\mathrm{ET}_{0} \times \mathrm{Kc}_{\mathrm{comp}}
$$

Where, $\mathrm{ET}_{\mathrm{c}}=$ crop evapotranspiration

$\mathrm{ET}_{0}=$ reference evapotranspiration

$\mathrm{Kc}_{\text {comp }}=$ composite crop co-efficient

Spatial $\mathrm{ET}_{\mathrm{c}}$ were generated during 2009 to 2014. The seasonal sum of $\mathrm{ET}_{\mathrm{c}}$ was used to compute season-specific AWD during 2009-2014 as stated below:

$$
\begin{aligned}
& \mathrm{AWD}=\sum_{\mathrm{i}}^{\mathrm{t}} \mathrm{ET}_{\mathrm{c}} \\
& \text { For } \quad \mathrm{AWD}_{\text {kharif }}=\sum_{\text {July }}^{\text {November }_{\text {et }}} \mathrm{ET}_{\mathrm{c}} \\
& \mathrm{AWD}_{\text {rabi }}=\sum_{\text {December }}^{\text {April }} \mathrm{ET}_{\mathrm{c}}
\end{aligned}
$$

Here, $\mathrm{t}$ is crop growing period.

3.3.4. Generation of regional scale $\mathbf{E T}_{\mathrm{a}}: \mathrm{ET}_{\mathrm{a}}$ was estimated using single-source surface energy balance framework with thermal observations from MODIS and MERRA reanalysis data (Eswar et al., 2016). ET $_{\mathrm{a}}$ was estimated as a product of fraction of incoming solar radiation converted into ET (or $\lambda \mathrm{E}$ in energy terms, $\left.\mathrm{Wm}^{-2}\right)$ converted into solar radiation $\left(\mathrm{R}_{\mathrm{sd}} \mathrm{Fact}=\lambda \mathrm{E} / \mathrm{R}_{\mathrm{sd}}\right)$ and incoming solar radiation $\left(\mathrm{R}_{\mathrm{sd}}\right)$ as stated below:

$\mathrm{ET}_{\text {day }}=\frac{\mathrm{R}_{\mathrm{sd}} \mathrm{Fact} \times\left(\mathrm{R}_{\mathrm{sd}}\right)_{\mathrm{day}} \times 24 \times 3600}{2.45 \times 10^{6}}$

where the subscript 'day' = time integrated value over 24 hours

The $\mathrm{R}_{\mathrm{sd}}$ was obtained from MERRA satellite analysis and $\mathrm{R}_{\mathrm{sd}}$ Fact was estimated from the triangle model (Jiang and Islam, 1999) through estimation of evaporative fraction (EF) using LST and NDVI (Eswar et al. 2013). EF obtained was converted into $\mathrm{R}_{\mathrm{sd}}$ Fact using the following equation as stated below:

$$
\mathrm{R}_{\text {sd }} \text { Fact }=\frac{E F \times\left(R_{n}-G\right)_{\text {inst }}}{\left(R_{\text {sd }}\right)_{\text {inst }}}
$$

$$
\begin{aligned}
\text { where }_{\mathrm{n}}= & \text { net radiation }\left(\mathrm{Wm}^{-2}\right) ; \\
& \mathrm{G}=\text { soil heat flux }\left(\mathrm{Wm}^{-2}\right) ; \\
& \mathrm{EF}=\text { evaporative fraction }
\end{aligned}
$$

The subscript inst'indicates the instantaneous value of the radiation components at the time of satellite overpass. $R_{n}, G$ and $R_{s d}$ were estimated from Mallick et al (2009). The RsdFactestimated was considered to be constant and was multiplied with 8-day averaged Rsdfrom MERRA to get 8-day averaged $\mathrm{ET}_{\mathrm{a}}$, which were then summed up for the monthly value. The time series of $\mathrm{ET}_{\mathrm{a}}$ were estimated from 2009-2014 and seasonal sum of $\mathrm{ET}_{\mathrm{a}}$ was computed for both kharif and rabi seasons.

3.3.5. Generation of regional scale ER: The ER at monthly scale was computed using USDA SCS method as stated below:

$$
\begin{aligned}
& \mathrm{ER}=\mathrm{P} \times \frac{(125-0.2 \times \mathrm{P})}{125} \text { for } \mathrm{P} \leq 250 \mathrm{~mm} \\
& \mathrm{ER}=125+0.1 \times \mathrm{P} \text { for } \mathrm{P}>250 \mathrm{~mm}(15)
\end{aligned}
$$

whereER $=$ effective rainfall

$\mathrm{P}=$ gross monthly rainfall

Seasonal sum of ER was computed for both kharif and rabi seasons during 2009-2014.

3.3.6. Estimation of Green and Blue water use efficiency: TheCWU was segregated into green $\left(\mathrm{CWU}_{\mathrm{g}}\right)$ and blue $\left(\mathrm{CWU}_{\mathrm{b}}\right)$ wateruse. In each grid cell, CWU was calculated as stated below:

$\mathrm{CWU}=\mathrm{CWU}_{\mathrm{g}}+\mathrm{CWU}_{\mathrm{b}}$

The green water was calculated as the sum of green water use for each month ( $\left.\mathrm{mm} \mathrm{month}{ }^{-1}\right)$ over the crop growth period. The month water use for crop composites in an agricultural cluster was computed as the minimum between the effective rainfall, agricultural water demand and actual evapotranspiration (FAO, 1956)as given below:

$$
\mathrm{CWU}_{\mathrm{g}}=\operatorname{minimum}\left(\mathrm{AWD}, \mathrm{ER}, \mathrm{ET}_{\mathrm{a}}\right)
$$

The blue water represents the crop's irrigation water use. The monthly blue water used for the production of crop composites in an agricultural cluster during a crop growing period, assuming that the irrigation requirements of the crop composites are fully met, is considered zero, if the actual evapotranspiration requirement is met by the $\mathrm{CWU}_{\mathrm{g}}$. Under this condition, the $\mathrm{CWU}_{\mathrm{b}}$ was computed as given below:

$$
\mathrm{CWU}_{\mathrm{b}}=\max \left(0, \mathrm{ET}_{\mathrm{a}}-\mathrm{CWU}_{\mathrm{g}}\right)
$$

The AWUE $\left(\mathrm{kg} \mathrm{C} \mathrm{m}^{-3}\right)$ was calculated as the ratio of the weight of crop produced (GPP in $\left.\mathrm{Kg} \mathrm{C} \mathrm{m}{ }^{-2}\right)$ to the volume of water $\left(\mathrm{m}^{3}\right.$ $\mathrm{m}^{-2}$ ) consumed as given below:

$$
\mathrm{AWUE}_{\mathrm{g}}=\frac{\mathrm{GPP}}{\mathrm{CWU}_{\mathrm{g}}} ; \mathrm{AWUE} \mathrm{E}_{\mathrm{b}}=\frac{\mathrm{GPP}}{\mathrm{CWU}_{\mathrm{b}}}
$$

\section{RESULTS}

Agricultural productivity is driven by availability and efficient use of water in a given agricultural cluster. Analysis of water use efficiency is an important indicator of the utilization of actual amount of waterin an agricultural system.

\subsection{Spatial scenario of productivity, water availability and water uses}

The major part of the Indian agriculture is dominated by monsoon during kharif season and it is a mix of irrigation and rainfall during rabi season. In order to investigate the green and blue water consumption in an explicit way, a detailed investigation of agricultural productivity in terms of GPP, water demand and water uses were carried out for both kharif and rabi seasons during 2009-2014 and the results are shown in Figure 2. 
b)
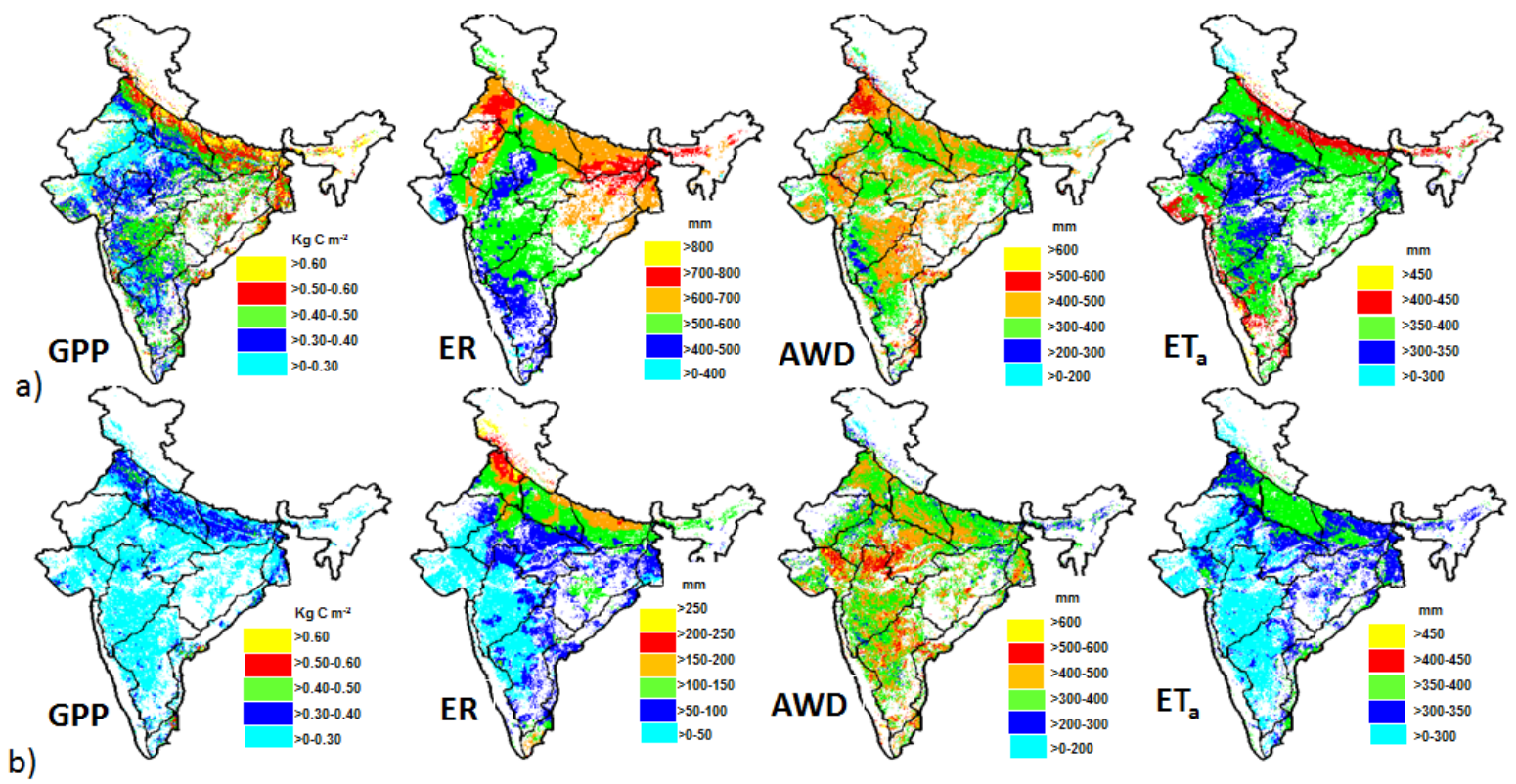

Figure 2: Spatial distribution of GPP, water availability and water usesover Indian regions,a) kharif; b) rabi season.

The average agricultural productivity measured through GPP showed significant spatial variability over India. The Indogangetic plains i.e. IGPs (TGP, UGP, MGP, LGP) showed the highest GPP $\left(>0.60 \mathrm{~kg} \mathrm{C} \mathrm{m}^{-2}\right)$ followed by the eastern parts ofIndia $\left(>0.40 \mathrm{kgC} \mathrm{m}^{-2}\right)$, southern and central parts $(>0.30 \mathrm{~kg}$ $\left.\mathrm{Cm}^{-2}\right)$ and the lowest GPP was observed in WDR $(<0.30 \mathrm{~kg} \mathrm{C}$ $\left.\mathrm{m}^{-2}\right)$.

The spatial distribution of average ER showed that among all the agro-climatic zones, IGPs showed the highest seasonal ER $(E R \approx 2673 \mathrm{~mm})$ with each gangetic plain showed seasonal sum of ER more than $600 \mathrm{~mm}$ whereas the low ER regions were observed as central and southern parts $(<600 \mathrm{~mm})$ and GPH $(<450 \mathrm{~mm})$ in kharif season. In rabi season, the highest ER was observed in theIGPs $(E R \approx 536 \mathrm{~mm})$ and the lowest ER was observed in GPH (ER $<20 \mathrm{~mm})$. Similarly for both AWD and $\mathrm{ET}_{\mathrm{a}}$, the IGPs showed the highest AWD and $\mathrm{ET}_{\mathrm{a}}$ in both kharif
$\left(\mathrm{AWD} \approx 1654 \quad \mathrm{~mm} ; \quad \mathrm{ET}_{\mathrm{a}} \approx 1500 \mathrm{~mm}\right)$ and rabi $\left(\mathrm{AWD} \approx 1541 ; \mathrm{ET}_{\mathrm{a}} \approx 1374 \mathrm{~mm}\right)$ seasons due to high crop intensification asobserved from highest GPP in those areas as compared to theother regions.

\subsection{Quantification of consumptive water uses at seasonal scale}

The seasonal CWU's $\left(\mathrm{CWU}_{\mathrm{g}}\right.$ and $\left.\mathrm{CWU}_{\mathrm{b}}\right)$ were analysedfrom 2009to 2014 and the results were taken as the baseline quantification ofAWUE over Indian agricultural area. The domain average(2009-2014) of $\mathrm{CWU}_{\mathrm{g}}$ and $\mathrm{CWU}_{\mathrm{b}}$ and their standard deviationare depicted in Figure 3.It has been observed from the analysis thatthe Indian agroecosystem is dominated by rainfed agriculture inkharif season while irrigated agriculture is practiced during rabiseason in major parts of the country. TheKharif season found to be far dominated by the $\mathrm{CWU}_{\mathrm{g}}$, as it

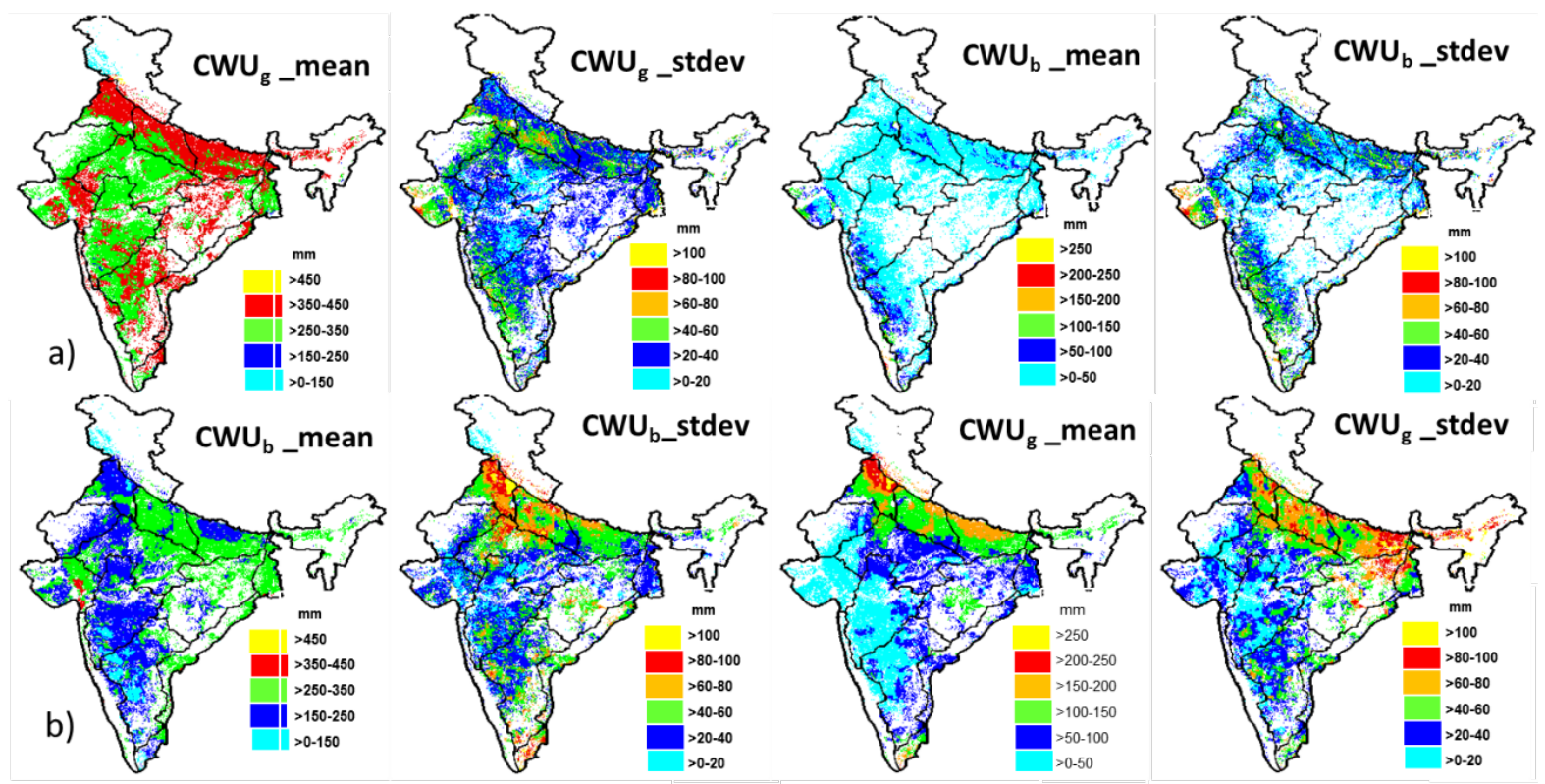

Figure 3: Average pattern and standard deviations of greenand blue water uses over Indian regions. 
accounts for the $85.38 \%$ (4807 $\mathrm{mm}$ ) of the total CWU (5630 $\mathrm{mm})$ as rainfall fulfils most of theagricultural water demand, whereas the $\mathrm{CWU}_{\mathrm{b}}$ contributed $14.62 \%$ (823 mm).In rabi season, the CWU (4585mm) was found to be segregated into $75 \%$ of $\mathrm{CWU}_{\mathrm{b}}(3449 \mathrm{~mm})$ and $25 \%$ of $\mathrm{CWU}_{\mathrm{g}}(1136 \mathrm{~mm})$ reflects that althoughmajor parts of AWD is met by the blue water but few areas still uses green water. Indian agriculture was found to be a mix of both rainfall and irrigation in both the seasons. The arid and semi-arid regions uses blue water in addition to green water in kharif season whereas IGPs that falls in the high rainfall zone as observed by the seasonal ER, and eastern parts of India and some parts in SPH use green water during rabi season due to NE monsoon effect.

The domain average of $\mathrm{CWU}_{\mathrm{g}}$ during kharif season showed highest green water use in the IGPs $(>1400 \mathrm{~mm})$ in which the share of $\mathrm{CWU}_{\mathrm{g}}$ in the ascending order was observed in the LGP (346 mm), UGP (365 mm), TGP (373 mm) and MGP (375 $\mathrm{mm})$. Except few regions such as GPH, UGP, WDR and SPH, where a deviation of $\mathrm{CWU}_{\mathrm{g}}$ of the order of $40-80 \mathrm{~mm}$ was observed and no significant deviation of $\mathrm{CWU}_{\mathrm{g}}$ was observed in other parts of India. The domain average of $\mathrm{CWU}_{\mathrm{b}}$ during kharif season showed large share in the arid, semi-arid and in parts of sub-humid regions such as WCPH (highest share $\approx 96 \mathrm{~mm}$ ), followed by GPH $(\approx 76 \mathrm{~mm})$, a part of WPH and $\mathrm{SPH}(>55$ $\mathrm{mm})$, the entire UGP and MGP $(>40 \mathrm{~mm})$ and these areas also showed a deviation of $\mathrm{CWU}_{\mathrm{b}}$ of the order of more than $20 \mathrm{~mm}$ and less than $80 \mathrm{~mm}$ indicating irrigation water usage. During rabi seasons, highest share of $\mathrm{CWU}_{\mathrm{b}}$ was observed in the IGPs $(1077 \mathrm{~mm})$ followed by EPH, ECPH and a part of GPH ( $>$ $260 \mathrm{~mm}$ ) and the significant deviation of $\mathrm{CWU}_{\mathrm{b}}$ of the order of more than $40 \mathrm{~mm}$ was observed in the IGPs, of which highest deviation of the order of more than $60 \mathrm{~mm}$ was observed in TGP, UGP, MGP indicating extensive use of blue water in addition to green water. This is followed by $\mathrm{CPH}, \mathrm{EPH}$ and lower part of $\mathrm{SPH}$, where the deviation of $\mathrm{CWU}_{\mathrm{b}}$ from the domain average was observed of the order of $40 \mathrm{~mm}-60 \mathrm{~mm}$. The rest part of the Indian region falls in the range of more than $20 \mathrm{~mm}-40 \mathrm{~mm}$ of deviation of $\mathrm{CWU}_{\mathrm{b}}$. The $\mathrm{CWU}_{\mathrm{g}}$ in the rabi season showed the highest share in the IGPs $(>480 \mathrm{~mm})$ and the lowest share was observed in the arid and semi-arid regions $(<50 \mathrm{~mm})$. The largest deviation of $\mathrm{CWU}_{\mathrm{g}}$ from the domain average was observed in the IGPs $(>40 \mathrm{~mm})$ and the least deviation was observed in the arid and semi-arid regions (WDR, GPH, WPH) of the order of $20 \mathrm{~mm}-40 \mathrm{~mm}$. It has been observed from the spatial analysis that green water plays a major role for sustaining food production in most of the agroclimatic regions of India as its contribution were observed in both kharif and rabi seasons as compared to blue water. The study had the similarity with the previous study (Falkenmark
And Rockstrom, 2004; Molden, 2007). The IGPs were found to be the "hotspots" (highest CWU) for green and blue water uses and also showed largest deviation from the domain average of green and blue water uses indicating most intensive agricultural productions during 2009-2014 in the country. Moreover, most of the rainfall occurs in this region during kharif season as observed from spatial distribution of ER (Figure 2) and has extensive irrigation application during rabi season for crop production.

\subsection{Tempoal variability of green and blue water usage in agricultural sector}

The temporal variability of green and blue water were investigated over the cropland during 2009-2014 (Figure4). The analysis was performed for both kharif and rabi seasons along with ER, AWD and CWU. Over the years, an increasing trendwas observed in $\mathrm{CWU}_{\mathrm{g}}(2.5 \%)$ and $\mathrm{CWU}_{\mathrm{b}}(0.5 \%)$ during kharif and rabi seasons, respectively. This trend was obviously related to the progressively increasing area of both rain fed and irrigated agricultural land around the country. During kharif season, AWD was found to be nearly equal to CWU in 2010 and 2011 but 2009, 2012 and 2014, being drought years as reported by IMD (IMD 2009, 2012, 2014), AWD was not found met by CWU. In rabi season, except 2010-2011 (being normal year), other years showed low CWU as compared to AWD, which is mainly attributed to the drought effects in those years. Corresponding to the drought years in both the seasons, GPP was also found low as compared to the normal years. Corresponding to GPP and CWU's, the analysis of quantification $\mathrm{AWUE}_{\mathrm{g}}$ and blue $\mathrm{AWUF}_{\mathrm{b}}$ over Indian agroecosystem at seasonal scale showed lower values during the drought years in both kharif and rabi seasons.

The AWUE $\mathrm{b}_{\mathrm{b}}$ during rabi season showed an increase trend (4\%) reflects increasing irrigation efficiency due to improvement in irrigation infrastructure whereas no significant change was observed in $\mathrm{AWUE}_{\mathrm{g}}$ during kharif season. The average $\mathrm{AWUE}_{\mathrm{g}}$ and $\mathrm{AWUE}_{\mathrm{b}}(2009-2014)$ were found to be $1.13 \mathrm{kgCm}^{-3}$ and $1.06 \mathrm{kgCm}^{-3}$ respectively with wide spatial variability over India (Figure 5).The IGPs showed the highest AWUE (AWUE ${ }_{\mathrm{g}} \approx$ $1.26 \mathrm{kgCm}^{-3}$ in kharif; AWUE $\mathrm{b} \approx 1.15 \mathrm{kgCm}^{-3}$ inrabi) due to high cropintensification and WDR showed the lowest AWUE $\left(\right.$ AWUE $_{\mathrm{g}} \approx 0.62 \mathrm{kgCm}^{-3}$ in kharif; $\mathrm{AWUE}_{\mathrm{b}} \approx 0.65 \mathrm{kgCm}^{-3}$ in rabi). Few agro-climatic regions such as GPH, parts of WPH, SPH and CPH regions showed low AWUE despite having high CWU. The analysis reveals the status of satellite based baseline assessment of AWUE at country scale for better agricultural water management with respect to climate change and food security.

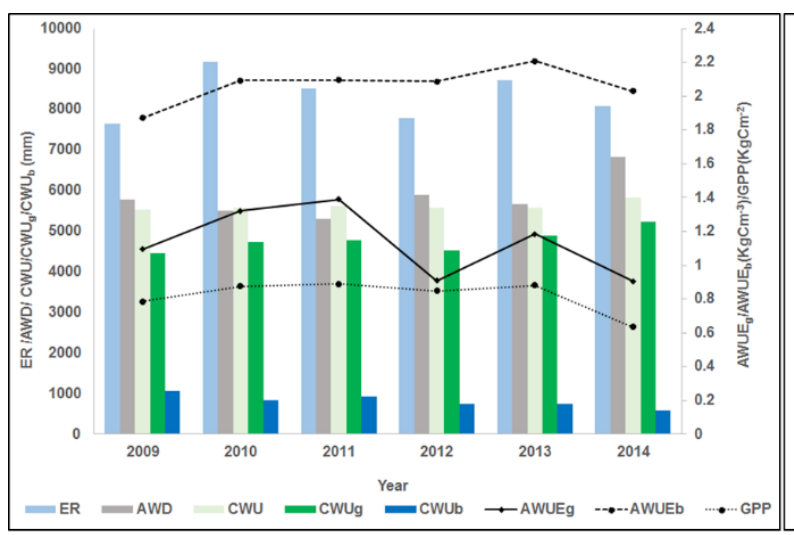

a)

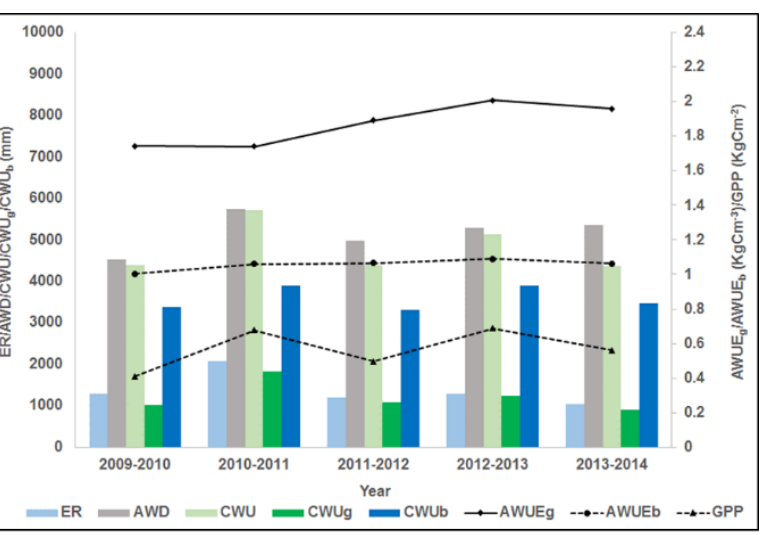

b)

Figure 4: Temporal variability of green and blue water use efficiency (2009-2014), a) kharif season; b)rabi season 


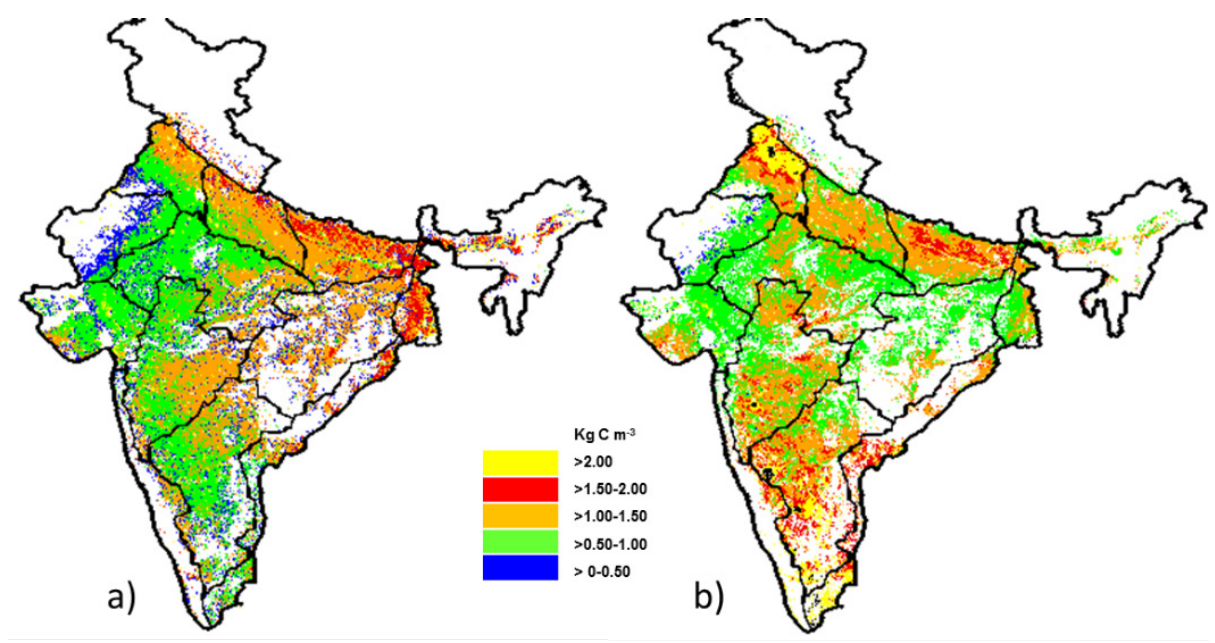

Figure 5: Average water use efficiency, a) kharif season; b) rabi season

\section{CONCLUSIONS}

The present study provides the baseline quantification of agricultural water use efficiency in cropland in spatially explicit way by taking into account both green and blue water components. The results showed that the average CWU (20092014) of Indian agriculture were found to be $5630 \mathrm{~mm}$ and 4585 $\mathrm{mm}$ during kharif and rabi seasons, respectively in the crop growing periods. Green water contributed to $85.36 \%$ of the total CWU in kharif season and this high proportion of green water was due to the dominance of rain fed agriculture in kharif season. In addition, in irrigated cropland, green water contributed $25 \%$ of the total CWU concentrating in the IGPs. This reflects the significant contribution of green water in Indian agriculture indicating the need for a better management of this water resource. The blue water contributed $75 \%$ in the rabi season and $14.64 \%$ in the kharif season, the major share goes to the IGPs due to better irrigation facility. The average $\mathrm{AWUE}_{\mathrm{g}}$ and $\mathrm{AWUE}_{\mathrm{b}}$ (2009-2014) during kharif and rabi seasons were found to be $1.13 \mathrm{kgCm}^{-3}$ and $1.06 \mathrm{kgCm}^{-3}$ respectively with highest share goes to the IGPs due to high crop intensification and lowest share goes to the WDR. Few regions such as GPH, parts of WPH, SPH and CPH showed low AWUE despite having high CWU. The results obtained in the present study can be used as an important input to prioritize the proportion of green and blue water allocation in Indian agroecosystemwith a scope for improving management of water resources. This will lead to develop decision support system for sustainable agricultural production with respect to climate changeand food security.

\section{ACKNOWLEDGEMENTS}

The study was carried out under the Project funded by the Department of Science and Technology (DST), New Delhi under the Women Scientists Scheme (WOS-A; reference no: SR/WOS-A/EA-1001/2015 (G)), and their support is gratefully acknowledged. The authors are also grateful to the Director, Space Applications Centre, ISRO, Ahmedabad, for motivating and encouraging to take up the study and providing the necessaryinfrastructure for carrying out the research work.

\section{References:}

Allen R.G, Pereira, L.S., Raes, D., Smith, M., 1998.Crop evapotranspiration: guideline for computing crop water requirements. FAO Irrigation and drainage paper No. 56, Rome: Food and Agriculture Organization of the United Nations, pp 26-40.

Bouman, BAM.2007. A conceptual framework for the improvement of crop water productivity at different spatial scales".Agricultural Systems,9, pp. 43-60.

Chapagain, A.K., Orr, S., 2009. An improved water footprint methodology linking global consumption to local water resources: A case of Spanish tomatoes. Journal of Environmental Management 90 (2), pp.1219-1228.

Chapagain, A. K.,Hoekstra, A. Y., 2004. Water Footprints of Nations.Value of Water Research 5 Report Series No. 16, UNESCO-IHE, Delft, The Netherlands, 2004.

Chapagain, A.K., Hoekstra, A.Y., 2011.The blue, green and grey water footprint of rice from production and consumption perspectives.Journal of Ecological Economics, 70, pp. 749-758.

Choudhury, I.,Bhattacharya, B. 2018. An assessment of satellite based agricultural water productivity over the Indian region, International Journal of Remote Sensing, 39 (8), 2294-2311.

Danielson, J.J., Gesch, D.B., 2011. Global multi-resolution terrain elevation data 2010 (GMTED2010).U.S. Geological Survey Open-File Report,2011, 26 pp.

Eswar, R., Sekhar, M., Bhattacharya, B.K., 2013.A simple model for spatial disaggregation of evaporative fraction: Comparative study with thermal sharpened land surface temperature data over India. Journal of Geophysical ResearchAtmospheres, 118, pp. 12029-12044.

doi: 10.1002/2013JD020813.

Falkenmark, M., 1995.Coping with water scarcity under rapid population growth.Conference of SADC Ministers, Pretoria, 1995. 
Falkenmark, M.,Rockstrom, J., 2006.The new blue and green water paradigm: Breaking new ground for water resources planning and management. Journal of Water Resources Planning and Management,132,pp. 129-132.

Hoekstra, A.Y., Virtual water trade: Proceedings of the International Expert Meeting on Virtual Water Trade, Value of Water Research Report Series No.12, UNESCO-IHE, Delft, 2003.

Hoekstra, A. Y., Hung, P. Q., 2002. Virtual Water Trade: a Quantification of Virtual Water Flows Between Nations in Relation to International Crop Trade, Value of Water Research Report.

IMD (India Meteorological Department). 2010. Annual Report. 2009-10,1 -3. Department of Agriculture \& Co-operation, Ministry of Agriculture, Government of India, India Meteorological Department. www.agricoop.nic.in

IMD (India Meteorological Department). 2012. Southwest Monsoon, End-of-season report,1 -14. India Meteorological Department.www.imd.gov.in.

IMD (India Meteorological Department). 2014. Annual Report. 2014, Department of Agriculture \& Co-operation, Ministry of Agriculture, Government of India, India Meteorological Department.http://metnet.imd.gov.in/imdnews/ar2014.pdf

Jiang, L., Islam, S., 1999. A methodology for estimation of surface evapotranspiration over large areas using remote sensing observations. Geophysical Research Letters, 26(17), pp. 2773-2776.

Khan, S., Tariq,C.Y., Blackwell, J., 2006. Can irrigation be sustainable? Agricultural Water management, 80(1-3), pp. 8799. doi:10.1016/j.agwat.2005.07.006.

Kijne, J., Barker,R., Molden, D., 2003. Improving Water Productivity in Agriculture: Editors'Overview". In Water productivity in agriculture: limits and opportunities for improvement, editedby J. Kijne, et al. Comprehensive Assessment of Water Management in Agriculture. UK: CABIPublishing in Association with International Water Management Institute (IWMI).

Lee, S.H. 2013 Potential vulnerabilities of Crops Virtual Water Trade using Crops Water Requirement and Network Analysis. Seoul National University Press

Liu, J., Zehnder, A. J. B., Yang, H., 2009. Global consumptive water use for crop production: the importance of green water and virtual water. Water Resources Research, 45, W05428, doi:10.1029/2007WR006051.

Liu, J., Yang, H.,2010. Spatially explicit assessment of global consumptive water uses in cropland: 20 green and blue water. Journal of Hydrology, 384, pp. 187-197.

Mallick, K., Bhattacharya, B.K., Rao, V., Reddy, D.R., Banerjee, S., Venkatesh, H., Pandey, V., Kar, G., Mukherjee, J., Vyas, S.P., Gadgil, A.S., Patel, N., 2009.Latent heat flux estimation in clear sky days over Indian agroecosystems using noon-time satellite remote sensing data.Agricultural and Forest Meteorology, 149(10), pp. 1646-1665, doi:10.1016/j.agrformet.2009.05.006.
Oki, T.,Kanae, S., 2006.Global hydrological cycles and world water resources.Science,313, pp. 1068-1072.

Rockstro“m, J.,Gordon, L., 2001. Assessment of green water flows to sustain major biomes of the world: implications for future ecohydrological landscape management. Phys. Chem. Earth Pt. B, 26(11-12), 8pp. 43-851.

Rost, S., Gerten, D., Bondeau, A., Lucht, W., Rohwer, J., Schaphoff, S., 2008.Agricultural green and blue water consumption and its influence on the global water system.Water Resources Research, 44, W09405, doi:10.1029/2007WR006331.

Seckler, D., Amarasinghe, U., Molden, D. J., de Silva, R., Barker, R., 1998.World water demand and supply, 1990-2025: scenarios and issues. IWMI Research Report 19, IWMI, Colombo, Sri Lanka.

Siebert, S.,Doll, P., 2008. The global crop water model (GCWM): documentation and first results for irrigated crops, Frankfurt Hydrology Paper 07, Institute of Physical Geography, University of Frankfurt, Frankfurt am Main, Germany, available at: www.geo.unifrankfurt.

de/ipg/ag/dl/fpublikationen/2008/FHP 07 Siebert and Doell 2008.pdf, 2008

Shiklomanov, I. A.,Rodda, J. C. (Eds.), 2003. World Water Resources at the Beginning of the Twenty-First Century, Cambridge University Press, Cambridge, UK, 2003.

Sim, K.M., Roh, K.A., So, K.H., Kim, G.Y., Jeong, H.C., Lee, D.B., 2010.Assessing Impacts of Global Warming on Rice Growth and Production in Korea.Journal of Korean Climate Change Research, 2, pp. 121-131.

Vorosmarty, C.J., Green,P., Salisbury, J., Lammers, RB., 2000. Global water resources: vulnerability from climate change and population growth. Science, 289,pp. 284-288.

Vyas, S., Nigam, R., Bhattacharya, B. K., Kumar, P., 2016. Development of real-time reference evapotranspiration at the regional scale using satellite-based observations.International Journal of Remote Sensing 37 (24), pp. 6108-6126, DOI: 10.1080/01431161.2016.1253895.

Yoo, S.H., Kim, T.G., Lee, S.H., Choi, J.Y., 2015. Trend Analysis of Projected Climate Data based on CMIP5 GCMs for Climate Change Impact Assessment on Agricultural Water Resources. Journal of Korean Society of Agricultural Engineers, 57(5), pp. 69-80. 